\title{
HISTORICO-ECONOMIC TRACES IN THE FORMER ISLAND CITIES OF ZADAR AND TROGIR
}

[Received February 11th 2015; accepted March 23rd 2015 - DOI: 10.21463/shima.10.1.o9]

\section{ZRINKA MENDAS}

$<$ z.mendas@gmail.com>

\begin{abstract}
This article explores historico-economic traces in the ancient cities of Zadar and Trogir in the Adriatic Sea. Islands in the past, they emerged later as small peninsula cities, connected by bridges, canals or both. The reasons for this were economic and political: to protect the islands' natural resources, trade and territoriality. The historicoeconomic angle, covering the early and late medieval period, offers insight into ancient, urban and economic traces in Zadar and Trogir. Findings suggest that the peninsula city space, representing the Mediterranean archetype, had an important purpose in organising political, economic and social life. Ancient traces point to the events contributing to the economic prosperity of Trogir and Zadar while urban traces remind us of the military and religious purpose of the peninsula city walls. Market squares served as the hubs of the economic life and influenced the development of various trading activities and artisan occupations. Such organisation of the peninsula-city space has created the foundations for a contemporary cultural heritage and has important implications for regional tourism. The biggest challenge for the administration lies in exploring creative ways of preserving the ancient peninsula city space, including artisan trades and archaeological artefacts. This requires stakeholder engagement between city planners, public and artisan tradesmen as well as finding and utilising various funding sources, including European Union funds, inward investment and education about heritage.
\end{abstract}

KEYWORDS: historico-economic traces, former island cities, peninsula city, Zadar, Trogir, Croatia

\section{Introduction}

Analysis in this paper centres on historical and economic facets of the ancient Dalmatian former island and now peninsula cities Zadar and Trogir that influenced the development of their contemporary cultural heritage and regional tourism. With this in mind, the focus is on the Croatian early and late medieval period, when the peninsula cities enjoyed economic prosperity while also being subject to a great power struggle in the Adriatic Sea, especially from the Venetian Republic. The geographical position of the peninsula cities, their isolation from the hinterland, and the scarcity of natural resources all played important roles in the region's specialisation in areas such as agriculture, fisheries, oysters and olive plantations, sea salt and cheese production. As historian Fernand Braudel observed of the Mediterranean region: "the meagre resources of land are added to the meagre resources of the sea” (1992: 110). Time was money and distance was first enemy of Mediterranean cities. This struggle against distance required "perpetual vigilance but also 
of chance and luck" (ibid: 263) as was the case of transporting food merchandise such as wheat, rye, rice and fruit, as well as other perishable goods like cotton and silk. Like other Mediterranean cities studied by Braudel (1992), Dalmatian cities led a complicated life and this gradually resulted in developing a specific economic framework based on the system of relationships with the surrounding countryside and neighbouring towns or islands. The traditional state economy was also under constant duress from nearby economic powers. These developments resulted in a re-thinking of spatial organisation with regard to political, military, religious, and social life, resulting in the shift from being island cities to peninsular ones.

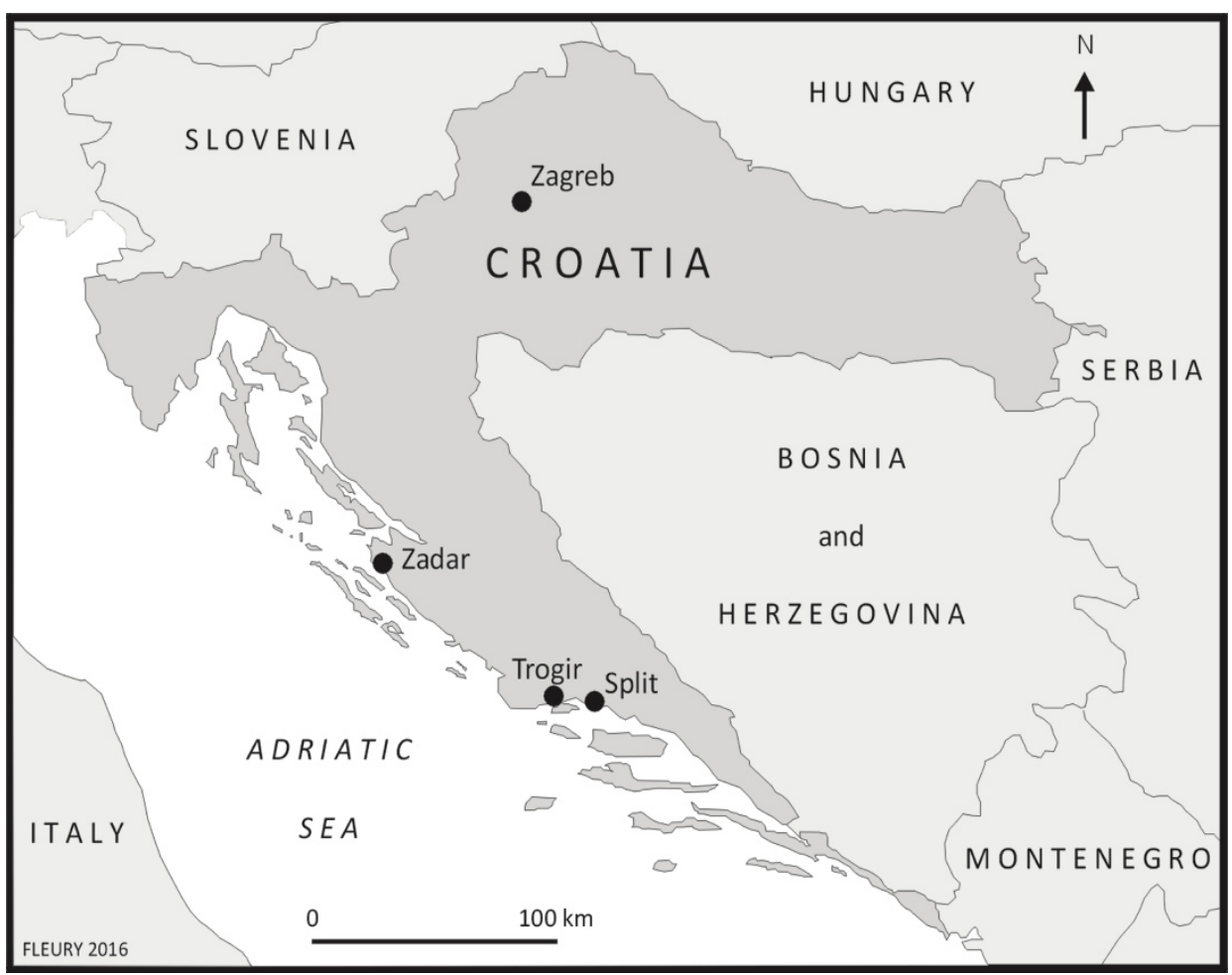

Figure 1 -Position of Zadar and Trogir within Croatia (Christian Fleury, 2016)

Ancient city and urban planners used canals and bridges to connect islands to hinterlands in order to protect invaluable island natural resources and territoriality. This practice, which resulted in the formation of many of today's urban peninsulas, is enjoying a revival. Copenhagen, for example, is encouraging the revival of the urban core of the island city (Desfor and Jørgensen, 2004). Canals were also typical of Dalmatian coastal regions. Using the notion of insularity, Faričić et al. (2014) classify island-peninsulas as both artificial peninsulas and pseudo islands. While artificial peninsulas can be created through insular connection to the mainland by means of dykes (eg the islands of Uljanik, Nin, Primošten, Rogožnica and Vranjić), pseudo islands are the result of insular connection to the mainland by means of bridges. As a result, these islands have lost some of their insular characteristics, especially in terms of transport connections to the mainland (Mendas, 2015). Other research on urban islands and island cities is pertinent to the discussion. 
Pigou-Dennis and Grydehøj (2014) discuss the problem of islandisation and deislandisation in urban planning in old European cities and support the argument that "islandness was not simply designed by a handful of decision-makers; it was constructed, put into practice, and maintained over the course of centuries by many thousands of city residents as well" (ibid: 272). This article examines the ancient peninsula cities of Trogir and Zadar. Perhaps the closest equivalent to these cities in the Mediterranean region are port cities (Baldacchino, 2014), of which there are numerous examples. Elsewhere in Europe, London, Southampton, Liverpool, London, and Bristol are all port cities with ancient links. Further south, Gold (2016) gives the example of Gibraltar and the influence of geography and the contemporary political situation in creating the peninsula city.

The UNESCO initiatives towards restoring medieval urban peninsula city spaces support the view that port and peninsula cities in the Adriatic Sea had political, economic and military value that city planners considered when developing or re-developing the city space. For example, Trogir enjoys the status of the UNESCO World Heritage city and Zadar's Episcopal Complex is being currently considered for its nomination. According to Grydehøj (2014), this value includes territorial, defence and trade transport benefits. Today, this is a part of cultural heritage, and with this in mind, the article discusses some aspects of the space.

\section{Framework}

This paper attempts to fill the void left by a lack of discussion of the Dalmatian cities in Adriatic Sea in Braudel's work, The Mediterranean and the Mediterranean World in the age of Philip II (1992). Braudel focuses on the Venetian Republic and relies on well-preserved archives in Venice, which may well be excused by the fact that Croatia's lesser status within the Yugoslavia's communist regime (1945-1991) effectively suppressed any flourishing of its intellectual life. Since Croatia's independence in 1998, there has been a significant revival in anthropological and archaeological studies of the medieval Croatian Republic. Arguably, the status of Roman municipalities enabled ancient Zadar, Trogir and other coastal cities to play a central role in consolidating the political, economic and communal life in the eastern Dalmatian region and consequently, their economic prosperity in the early and late medieval period. Today, this prosperity can be found in ancient, urban and economic traces in the use of the peninsula city urban space. Due to their geographical and strategic position, these were vital economic spaces for flourishing trade in the Adriatic Sea. At the same time, the connectedness of these peninsulas cities to the hinterland, whose closeness influenced trade development from peninsula to hinterland and vice versa, inevitably, led city planners to re-think the use of the urban core in peninsula cities. This brief prelude gives rise to two concerns: the notion of space and traces.

The term 'historico-economic' is consistent with the Annales School of History (Stoianovic, 1976), ${ }^{1}$ of which Fernard Braudel was member. Braudel, like Bloch, argues that

\footnotetext{
${ }^{1}$ Braudel was part of a group of French scholars who sought to infuse an historical orientation into the social and human science (Stoianovic, 1976). It resulted in the influential journal, Annales, underpinned by the philosophical approach Hemes and Hestia; a spatial relationship between space and human action as well as the dialectics between space and time (geography and history) (Stoianovic, 1976).
} 
method for historical economic analysis must be based on observations and systematic comparison. ${ }^{2}$ That is, it must have: (i) definition of a fact as a construct; (ii) duration at a quasi-immobile level of structures and traditions; (iii) a level of middle range duration of conjectures or periodic cycles of varying length and (iv) a level of short duration of events with the full life cycle (Stoianovic, 1976: 109). To understand the principles of the state economy of medieval Europe, as Braudel argues, one should study interactions between economic and material life. He writes, "While economic life comprises of commerce, its currencies, its nodal points and its superior equipment - great trading cities, stock exchanges and fairs, material life signifies the non-economy, imprisoned within selfsufficiency" (1982: 22). Inevitably, such an approach requires a comparative method $^{3}$ developed by Bloch (1953) which Braudel puts to test in the context of the pre-industrial period of the world and Mediterranean history, using his approach, la longue durée (1981). And like Braudel, I am interested in material life since it represents everyday life and happenings and unique repeated events ${ }^{4}$ that eventually become structures. ${ }^{5}$ These events, as Braudel argues, are plastic and the product of very slowly changing or relatively stable noneconomic, natural, cultural as well as political, economic, and technological factors. Braudel provides examples of the events of short-term temporal and spatial interferences that benefited, for example, merchants who exploited its instabilities so to take calculated risks and bring situation under control (eg ill wind, storms or sea piracy that caused loss to their revenues) (ibid: 223). Studying everyday material life involves anecdotal evidence or collections of little details, such as, travellers' notes, or the way people eat, dress or lodge at the different levels of that society. These stories can lead to a better understanding of the contrasts and disparities between societies (Braudel, 1981). ${ }^{6}$

\footnotetext{
${ }^{2}$ On this, Braudel writes, "The only possible method was observation - repeated until the eyes ached; then a call for assistance from different human sciences, and above all systematic comparison, the bringing together the experiences of the same nature" (1982: 22).
${ }^{3}$ Bloch asserts, "From the moment when we are no longer resigned to purely and simply recording the words of our witnesses, from the moment we decide to force them to speak, even against their will, cross-examination becomes more necessary than ever" (1954: 64).

\footnotetext{
${ }^{4}$ To recognise the significance of the events in Braudel's manner, they must: (i) have explanatory function, (ii) have spatial and or temporal consequence, (iii) be significant for contemporariness, (iv) serve as the signs of historical craft (Bloch's cross-examination), and (v) contribute to the formulation of a series, whether economic or political, social and cultural) (Stoianovic, 1976: 231).

${ }^{5}$ Baudel explains, "Everyday life consists of the little things that hardly one hardly notices in time and space. The more we reduce the focus of vision, the more likely we are to find ourselves in the material life... If we reduce the length of time observed, we either have the event or the everyday happening. The event is, or is taken to be unique, the everyday happening is repeated, and the more often it is repeated the more likely is to become a generality or rather a structure" (1981: 29).

${ }^{6}$ Braudel maintains, "Sometimes a few anecdotes are enough to set up a single event which points to a way of life... Through little details, travellers' notes, a society stands revealed. The way people eat, dress or lodge, at the different levels of that society, are never a matter of indifference. And these snapshots can also paint out contract and disparities between one society and another which are not all superficial" (1981: 29).
}

\section{Shima: The International Journal of Research into Island Cultures} Volume 10 Number 12016 
In a modest attempt to address Braudel's shortcomings, this paper explores historicoeconomic traces in Zadar and Trogir. I refer to a 'trace' as a non-linear or chronological ${ }^{7}$ contingent strategy ${ }^{8}$ that involves interweaving the text to arrive at a modified present, as Derrida $(1978,1981)$ argues. I try to reconstruct the reality - ancient, urban and economic using the historical and socio-economic data. The notion of a trace, in this sense, has a useful purpose. In this context, traces can also be viewed as short-term events, in Braudel's sense. It is up to the actors to convert these traces (events) into "signs" to create heritage. Signs exhibit themselves as material life:

which presents itself to us in the anecdotal from of thousands and thousands of assorted facts... little facts which do, it is true, by indefinite repetition, add up to form linked chains. Each of them represent the thousands of others that have crossed the silent depths of time and endured. (Braudel, 1981: 560).

It could therefore be argued that heritage appears to be a direct outcome of the short-term events taking place in the time and space of the medieval Adriatic. The author shows that the 'space' (urban morphology, architecture and the maritime location) is a key factor for economic prosperity. Both the pre-industrial and present economies take advantage of these factors. Therefore, today's time reframes this space by displaying the 'traces' in a new narrative and turn them as a material support for economy. On a final note, Braudel's method, la longue durée, looks at a spatial relationship between space and time, this paper provides an extension to his work on the Mediterranean region by focusing on peninsula cities in the Adriatic Sea as an active unit of spatial economic analysis. For simplification purposes, one could view the peninsula city as a collective of the individuals (ie businessmen, traders, artisans and citizens) who are engaged in elementary production producing and demanding the goods and services, which are circulated within the communal space (within the island and between other islands and the hinterland). The exchange of goods exists in local products (ie olive oil, food, salt and timber) and services (ie housing, maritime trade and shipbuilding), and other local business services within the peninsula space and between the peninsula and the hinterland (ie various artisan occupations such as stonemason, tailor and carpenter). In this way, I establish a basic economic activity needed to examine the economic space and its activities. I shall examine these aspects under the section concerning the economic traces in more detail.

The discussion that ensues is a conjectural sketch with historico-economic traces organised around three essential features: i) ancient, ii) urban and iii) economic traces. Ancient traces provide an insight into the major historical events that influenced the development of the peninsula cities of Trogir and Zadar between the 1oth and 16th centuries, that is, the early and late medieval period (for example, before and during the occupation by the Venetian Republic). This is followed by the urban traces that arose as a

\footnotetext{
${ }^{7}$ Derrida has written that, "This trace relates no less to what is called the future than what is called the past, and it constitutes what is called the present by the very relation to what it is not, to what it absolutely is not; that is, not even to a past or future considered as a modified present" (1978: 394$)$.

8 Trace is a contingent strategy, a "bricolage" for Derrida that helps him produce a new concept of writing (as opposed to the Socratic or Saussurean speech), where, the "interweaving results in each 'element' - phoneme or grapheme - being constituted on the basis of the trace within it of the other elements of the chain or system. This interweaving, this textile is the text produced only in the transformation of another text" (Derrida, 1981: 387-88).
}

\section{Shima: The International Journal of Research into Island Cultures} Volume 10 Number 12016 
direct consequence of ancient traces. Both ancient and urban traces were the main reasons for the economic traces.

\section{Discussion}

\section{Ancient Traces}

A detailed chronological review of medieval Croatian history can be found in Budak and Raukar (2006). Since the early and late medieval period had a vast influence on the contemporary development of the peninsula cities, this paper analyses two types of peninsula cities: the island of Trogir connected by bridges to the hinterland and peninsular Zadar's Poluotok, connected by canals from the hinterland to the city. Since bridged islands are part of the hinterland, I can speak of them as peninsula cities in the broader sense. Both Trogir and Zadar are close to each other and were built in the 4th Century as part of the Roman Empire and given the status of city municipalities. Both resisted the Venetian Republic until the 12th Century but remained under its control for the next 200 years.

Connected to the mainland by bridges, medieval Trogir city island lies in the strait between the hinterland and the island of Čiovo. Today, it is under the jurisdiction of SplitDalmatia county and has a population of 13,192, of which 10,923 reside in old Trogir (Croatian Bureau for Statistics, 2011: 48).

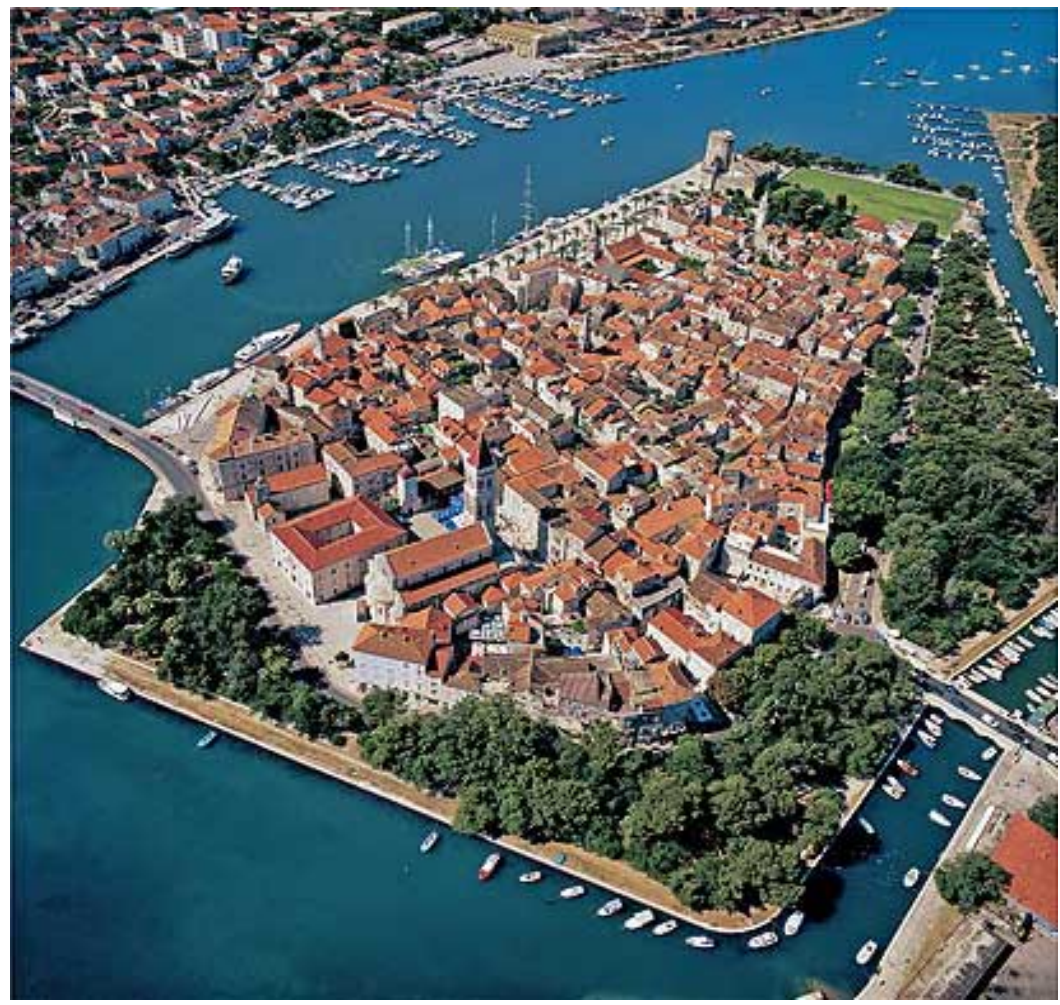

Shima: The International Journal of Research into Island Cultures Volume 10 Number 12016 
Figure 2 - Aerial photo of Trogir @ Croatian National Tourist Board (nd)

Built in the 3rd and 4th centuries by Greek nomads, Trogir's medieval name was Tragurion. While within the Roman Empire, Trogir had the municipality status Tragurium civium Romanorum and served, alongside Salona, as the centre of the Roman province of Dalmatia. The 5th Century coincided with the fall of the Roman Empire and this meant that cities began enjoying their free, independent city status. The arrival of Croats in Dalmatia in the 5th Century marked the beginning of the Croats' permanent settlements across the Dalmatian coast and Trogir and the establishment of the Royal Kingdom of Croatia in 925 under the leadership of the first Croatian King Tomislav (c. 910-928) by the Papal chancellery in Rome. The 1oth Century was also marked by a military invasion by the Venetian Republic ${ }^{9}$ who saw it as an opportunity to establish, for the first time, a power base in south Dalmatia. Trogir sought protection from the Hungarian King Koloman, who gained political control in the region. The 11th Century was a relatively peaceful period and it was not until 12th Century that the Venetian Republic again made attempts to take control of the city during periods of war with Hungary. They finally succeeded in 1420. Figure 3 illustrates the political and administrative units of the Venetian Republic.

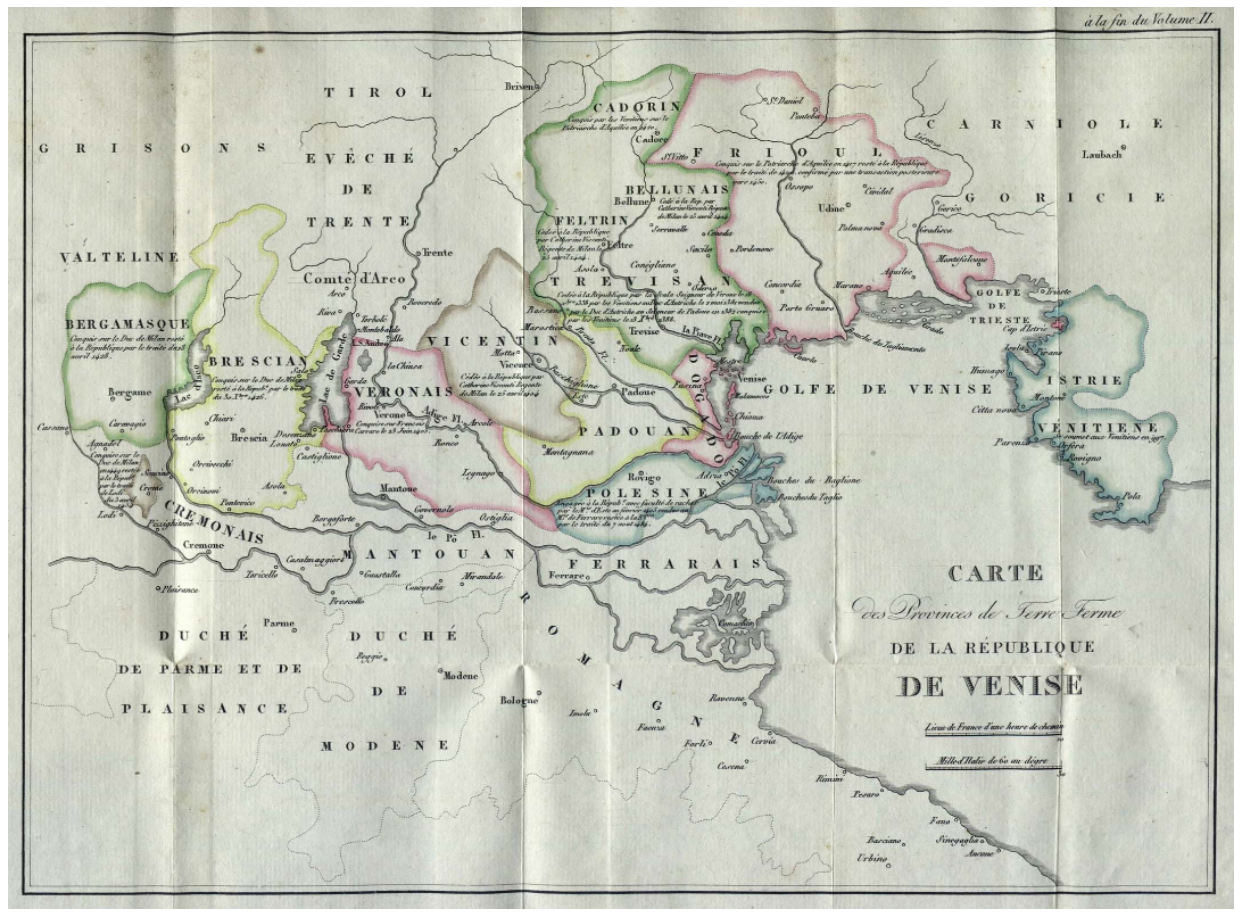

Figure 3 - Map of Venetian Republic in 1796 (Source: Daru [1819])

\footnotetext{
${ }^{9}$ The Republic of Venice, or traditionally known as the Most Serene Republic of Venice, existed from the late 7 th Century AD until 1797
} 
Under the newly gained jurisdiction of the Venetian Republic were also the Dalmatian cities of Zadar and Trogir as well as other cities held until 1797. After the fall of the Venetian Republic there was a short period of independence until Napoleon seized control of the city. After Napoleon, the Hapsburgs took it under their wing between 1814 and 1914. After the First World War, Trogir, together with Croatia, became part of the State of South Slovenes and after the Second World War, it become part of Yugoslavia. After the breakup of Yugoslavia in 1991, Trogir again become part of an independent Croatian Republic. Trogir's remarkable example of urban continuity, including an orthogonal street pattern dating back to the Hellenistic period, its fine Romanesque churches, along with its outstanding Renaissance and Baroque buildings from the Venetian period, gained it the status of a UNESCO World heritage site at the World Heritage Committee's 21st \meeting in Naples, Italy, 1-6 December 1997 (UNESCO, nd).

Like Trogir, the peninsula city of Zadar is situated on the hinterland but its old urban city centre, Poluotok, was developed on the peninsula. Poluotok was originally an island that was later connected by canals built to provide easy access.

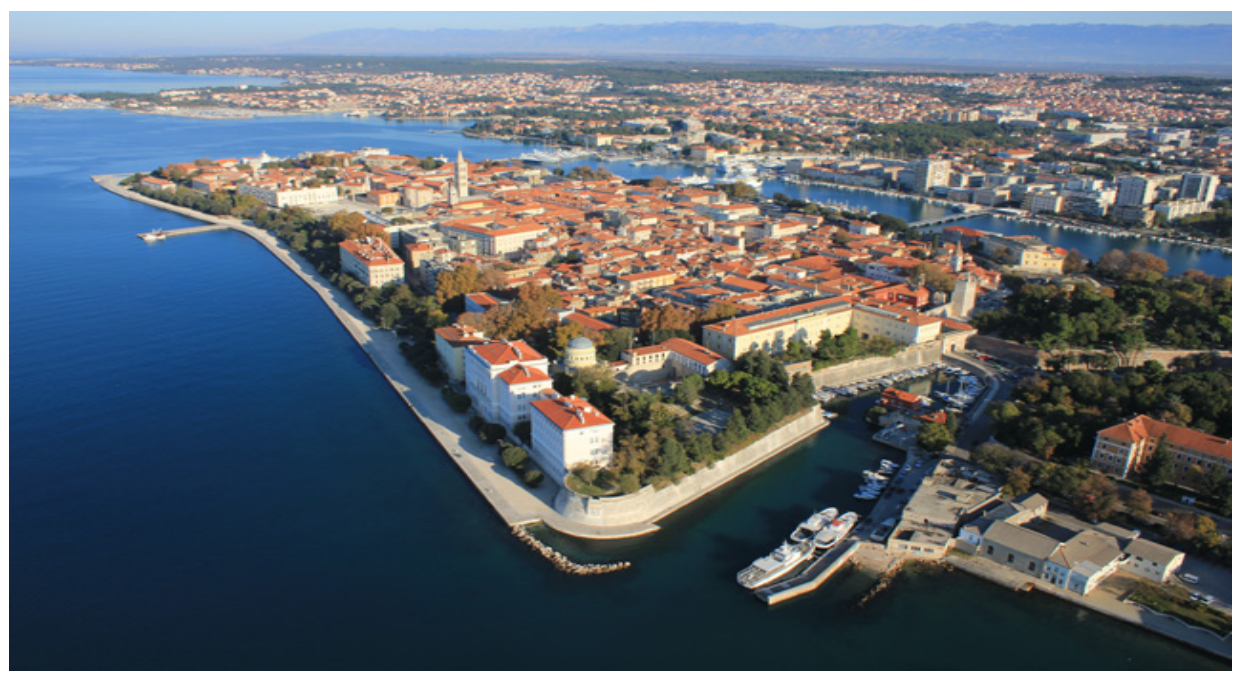

Figure 4 - Zadar's Poluotok @ Zadar Tourist Board (nd)

Built in the 4th Century, Zadar's first settlements were established by the Illyrian tribe, the Liburnians. Today, the port road still bears this name. Its first name, Jadera, was of Roman origin. After the end of the Roman Empire, it changed to Idassa, from Greek nomads' influence. Later, under the rule of the Venetian Republic and Italy, it changed its name to Diadora, then Zara, before the final name Zadar. In the 5th Century BC Zadar was, like Trogir, a Roman municipality in the Mediterranean region. The 1oth Century saw larger permanent settlements of Croats. Zadar's economic prosperity also became a major hindrance to the ambitions of the powerful Venetian Republic in the Adriatic and Mediterranean Seas and consequently, a major source of conflict between the Venetian Republic and the Croatian-Hungarian rulers. The period between the 11th and 14th centuries was a 'golden age' for Zadar and after 1069 Zadar with other Dalmatian communities came under the protection of Croatian King Petar Kresimir IV. After the death of King Dmitar Zvonimir in 1089, Zadar was from under the political control of the 
first Croatian-Hungarian king, Koloman, from 1195 on. In 1202, the Crusaders and Venetians conquered the city during the Siege of Zadar. The Croatian-Hungarian King Bela IV tried to re-establish political control over Zadar from 1242 to 1247 but was able to do so only after the Hungarian-Venetian War (1356-1358) when King Louis I of Anjou succeeded in defeating Venice and placed the city back under Bela's wing. Encouraged by this, Split and Trogir also expelled Venetian royals from their cities in 1357. Luis drafted a peace agreement, the Treaty of Zadar, between the Croatian-Hungarian King Louis I of Anjou and the Venetian Republic on 18th February 1358. Afterwards, the hinterland around Zadar came under the control of the Austrians until 1797, then the French from 1806 to 1813 , and then the Austrians again until 1918. Later, Zadar achieved the status of capital of the Kingdom of Dalmatia until 1919. However, the newfound freedom was shortlived; under the Treaty of Rapallo ${ }^{10}$ in 1922 Zadar was annexed to Italy until the end of the Second World War. After the war, it was annexed to Croatia within the Federal Republic of Yugoslavia. In 1991, Croatia split from the Federation and annexed Zadar back to the newly re-established Republic of Croatia.

For both Zadar and Trogir, historical circumstances, uninterrupted settlements, and Roman municipality status helped in shaping the early medieval urban characteristics of the peninsula cities, giving them the appearance of a typical Roman town (Jović-Gazić, 2012) with the city's urban space as a prominent feature. The next section explores some issues related to the organisation of urban space.

\section{Urban Traces}

The geographical attractiveness of peninsula cities on the one hand, and the continuous power struggle on the other, have both had a significant impact on the urban development of Zadar and Trogir. The constant threat from the Venetian Republic placed the city's political elite in the centre of the development and management of urban space. This resulted in features such as a military style of architecture and the fortifications of the island walls alongside the urban city centre in the middle. A well-preserved engraving (Figure 5) illustrates the early medieval city planning for Trogir.

\footnotetext{
${ }^{10}$ The Treaty of Rapallo was signed by Germany and the Russian Soviet Republic on April 16th 1922, as part of a plan to encourage economic recovery after World War I.
} 


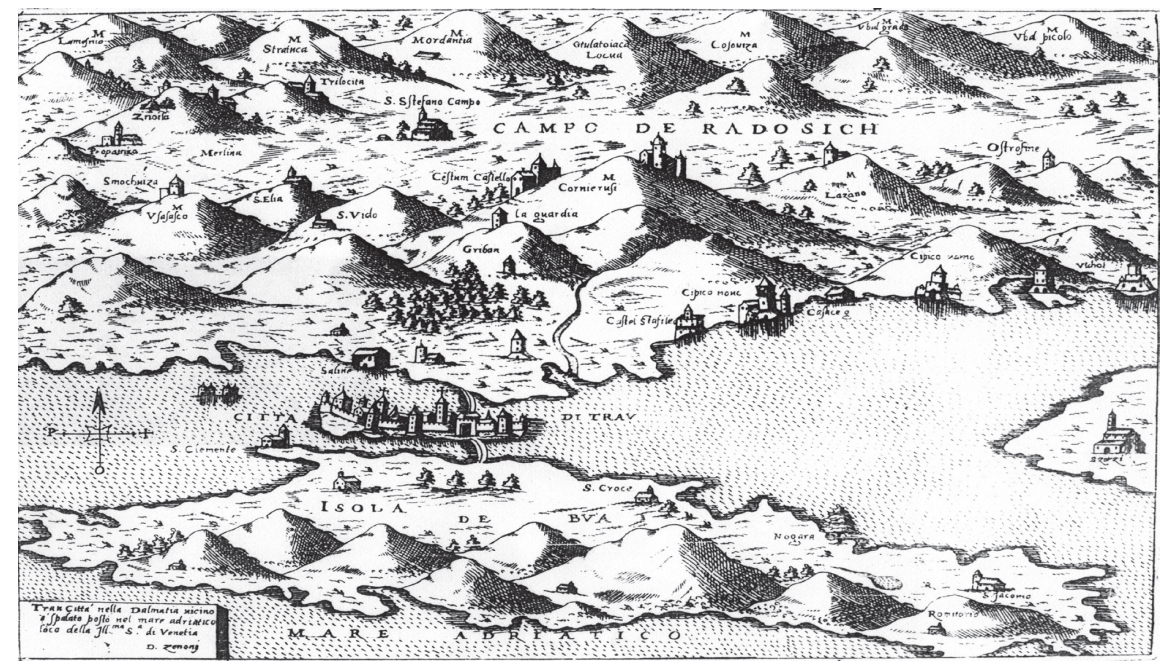

Figure 5 - Engraving of the City of Trogir - Old Plan (Source: Marković (2001) [1572])

This invaluable engraving from the second half of the 15th Century is stored in the graphic collection of the Croatian State Archives. It illustrates a strategic position of the fortresses built within Trogir and the nearby island and hinterland and, thus, an early attempt at spatial planning that includes not only the hinterland but also nearby strategically important islands, for example, Čiovo. What can also be observed is that ancient spatial planning did not only focus on the external regional space of the nearby hinterland and islands but also on internal urban city space that was organised and re-organised to provide protection to the citizens within its walls. Given the spatio-temporal circumstances, organisation of urban space was in the hands of the political elite serving the roles of both administrative and military bodies. Early evidence of the process of development of the urban space within Trogir is illustrated in Figure 6. 


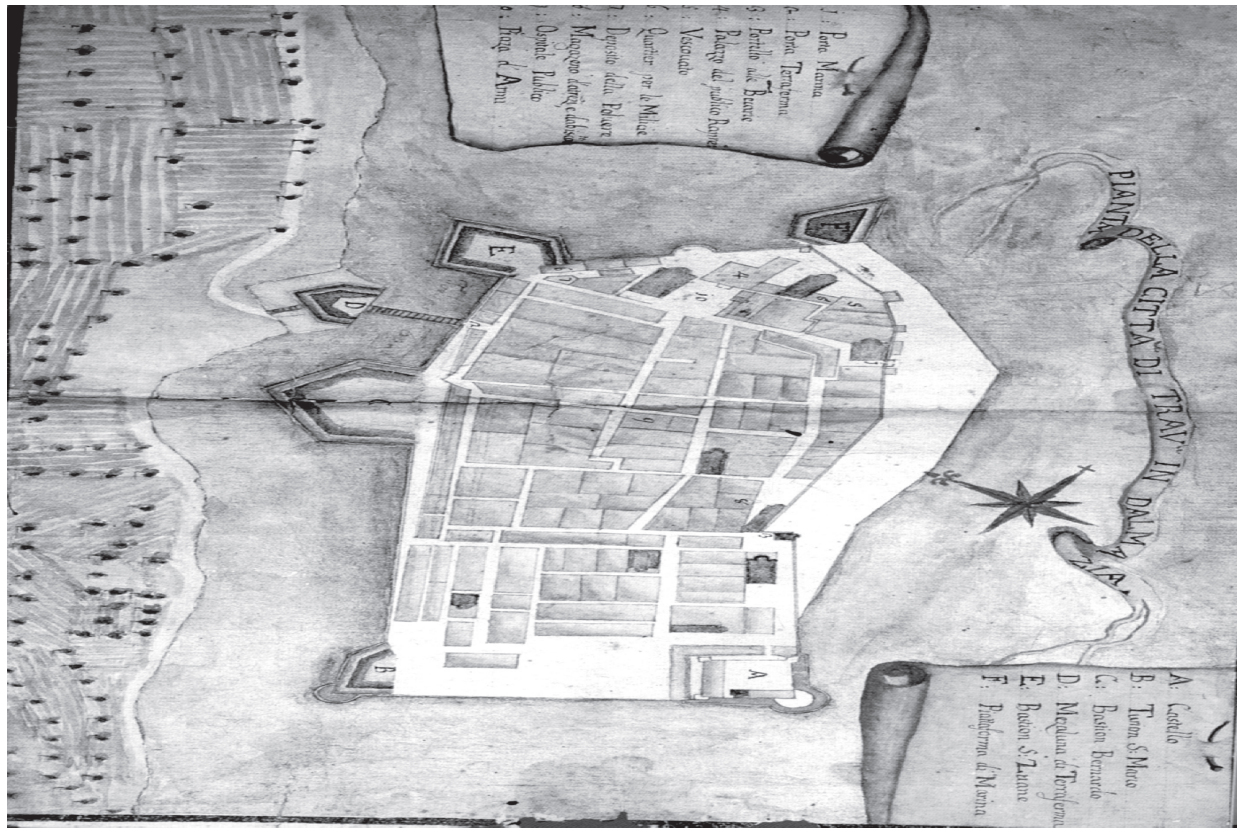

Figure 6 - City plan originating from 1755 (1359) (Source: Museum of Trogir city [nd])

The above map from the 17th Century illustrates early archetypal topographic work related to the Mediterranean medieval peninsula city. City edges were walled by the fortifications, which were surrounded by the churches, squares, city gates, towers and citizens' homes. Town streets were narrow and organised in networks, leading to the churches and squares in the middle and to the gate towers and private citizens' homes. They remain well preserved today, as seen in Figure 7. 


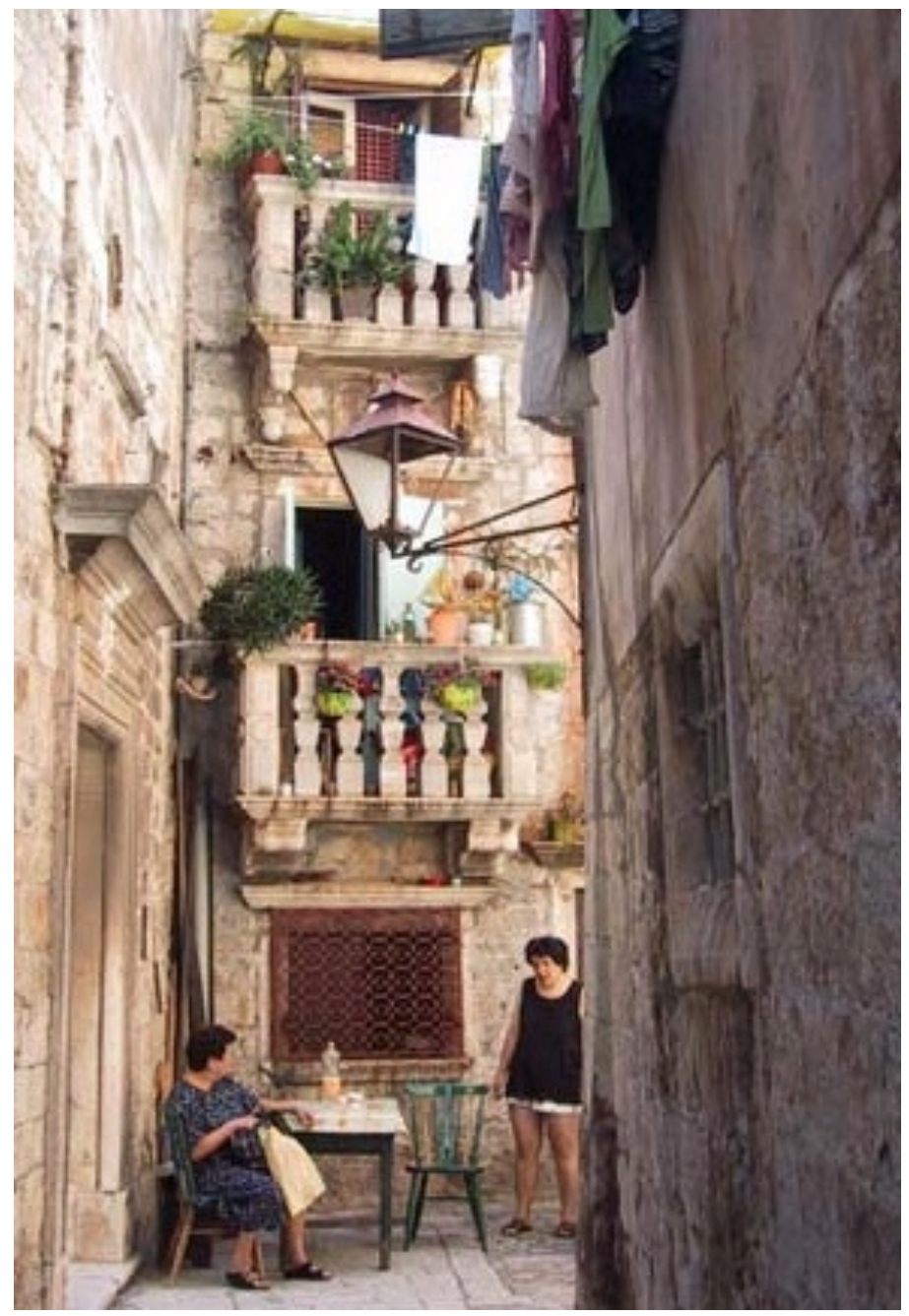

Figure 7 - A street in the Old Town of Trogir (c) Croatian National Tourist Board (nd)

Planning of urban space, in this manner, ensured defence and functional organisation (Lučić, 1993; Kovačić, 1998). Figure 6 also reveals the location of the churches within the urban city core. Indisputably, the Catholic Church had a prominent role in the city's secular decisions involving the use of urban space in the early Middle Ages. When the Vatican recognised the status of the Royal Kingdom of Croatia in the year 925 under the lead of the first Croatian king, Tomislav (c. 910-929), the church's influence in State affairs increased. Its wealth was generated by various income streams, including tax, income from the country, legacies and donations. In support of this argument, Chevalier (1995) provides interesting insight into the presence and influence of the Catholic Church in the Dalmatian region. His cartographic map, see Figure 8, reveals peninsula cities such as Zadar and Trogir, alongside others coastal cities, as the hubs of the religious influence and activities. 


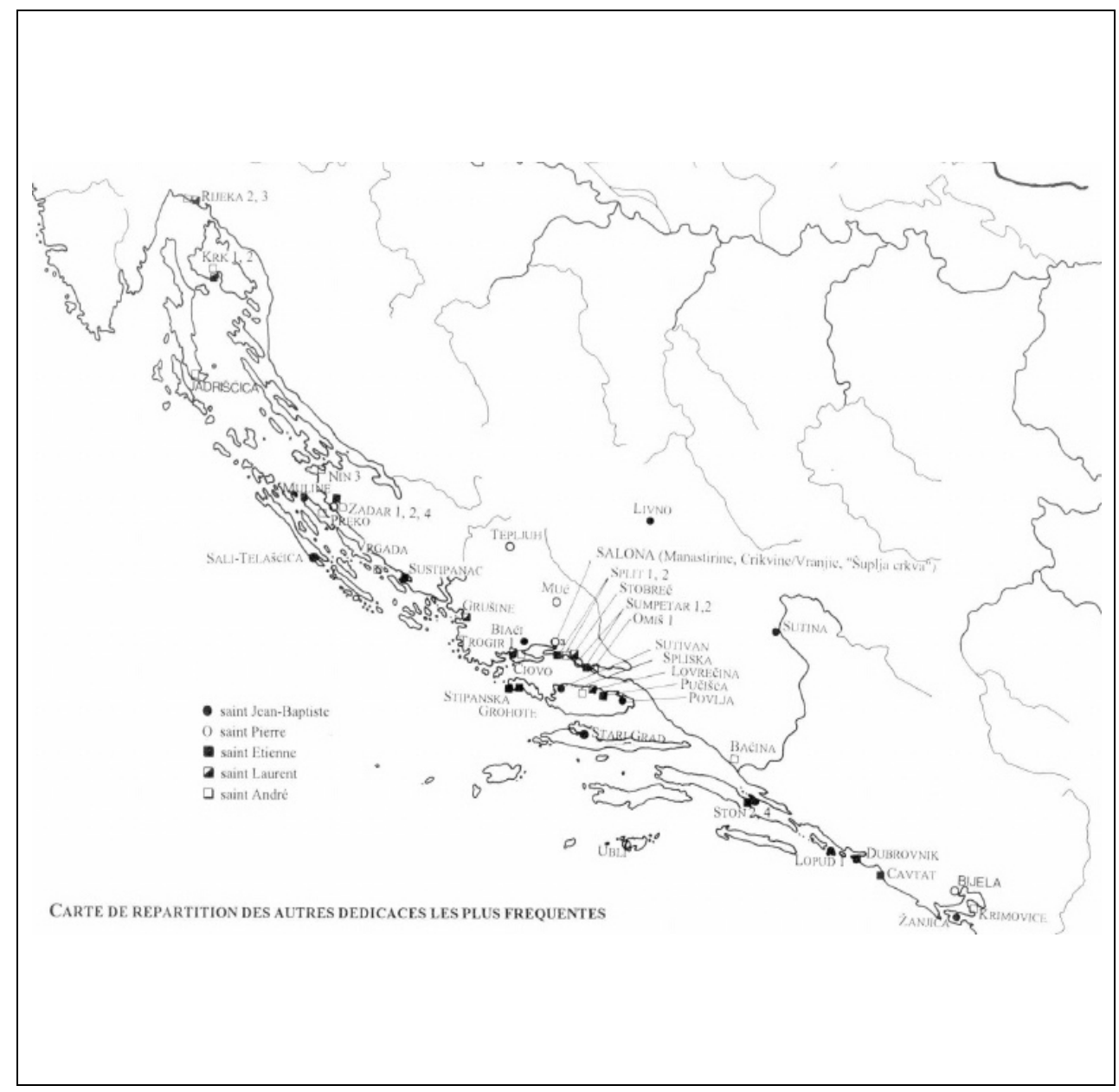

Figure 8 - The extent of the Catholic Church in the Dalmatian region in the medieval period (Source: Chevalier, 1995: 40)

Benyovsky (2006) discusses this in more detail while focusing on the process of development urban space. As Figure 9 illustrates, the biggest churches were in the centre of Trogir while the smaller ones were around the city walls. 


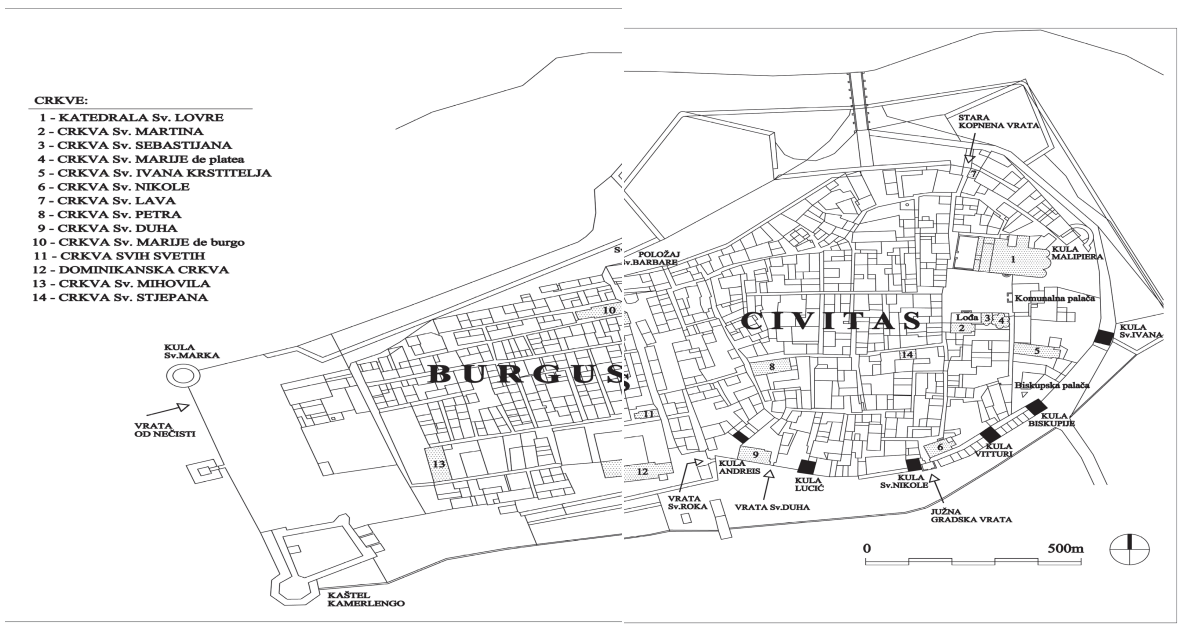

Figure 9 - Cadastral map of the city of Trogir in 1830 (Source: State Archive Split [N.D.])

This map from the 18th Century gives a glimpse into city defence planning, including the location of the churches in the period, which was determined by defensive considerations related to attacks from the Venetian Republic. The presence of numerous churches, such as St. Ivan Baptist, St. Martin and St. Nicholas, signalled the political and economic influence of the Catholic Church in city affairs. It unavoidably led to rise of rivalry between city's royalty and the Church and in the early 14th Century, the city council managed to separate political and secular interests from the religious. One could argue that in many ways, the period between the 1oth and 16th centuries in Trogir marks the early development of the modern organised urban island city system, not only in the Adriatic region but also in the entire Mediterranean region (Benyovsky, 2006). It would be useful to discuss how this development contributed to the organisation of space in more detail; however, this is beyond the scope of this article and merits future research in this field. Zadar, like Trogir, embraced the style of the typical Roman city. Roads were organised in networks that remain, as Figure 10 illustrates, still well preserved today. 


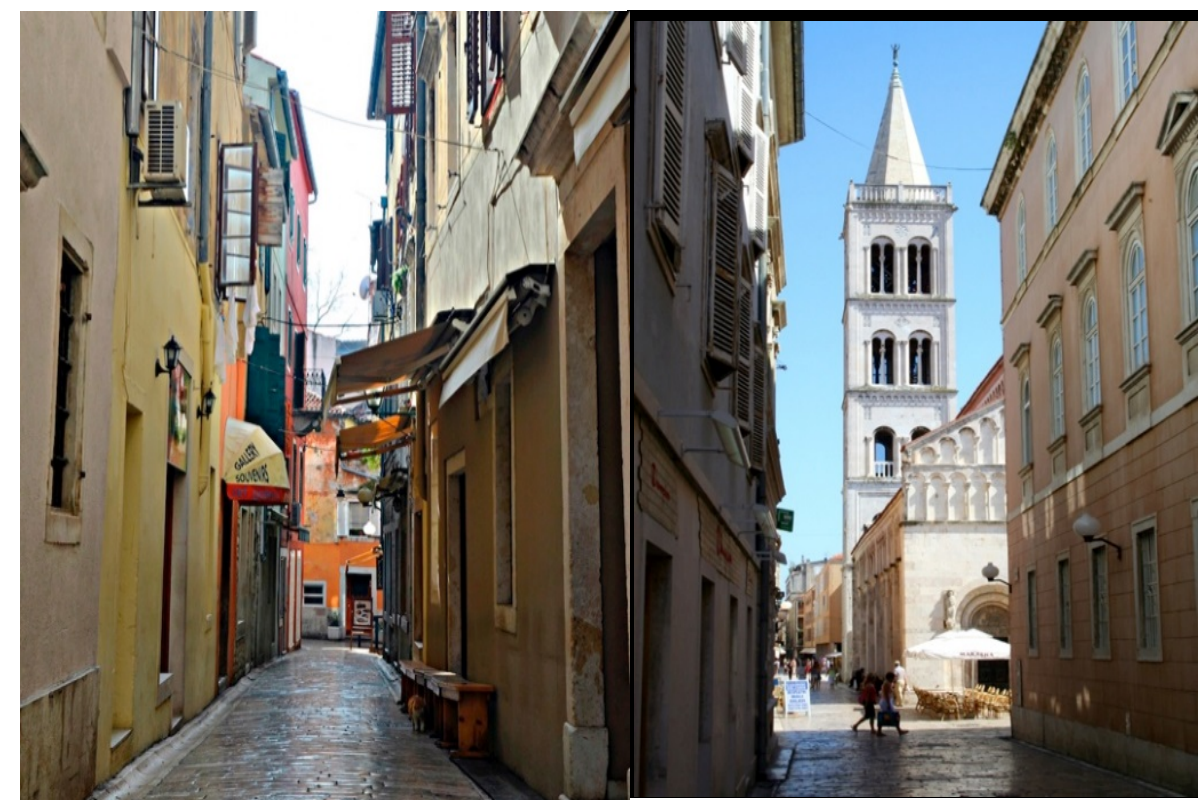

Figure 10 - Old Street in Polutok @ Tourist Board Zadar (nd)

As is typical for a Roman municipality, roads led to the main square, the forum, alongside the nearby capitolium, a Roman style temple. In the 9th Century, the new forum, the Church of the Holy Trinity (today known as St. Donat), replaced the old one in the centre, as seen in Figure 11. 


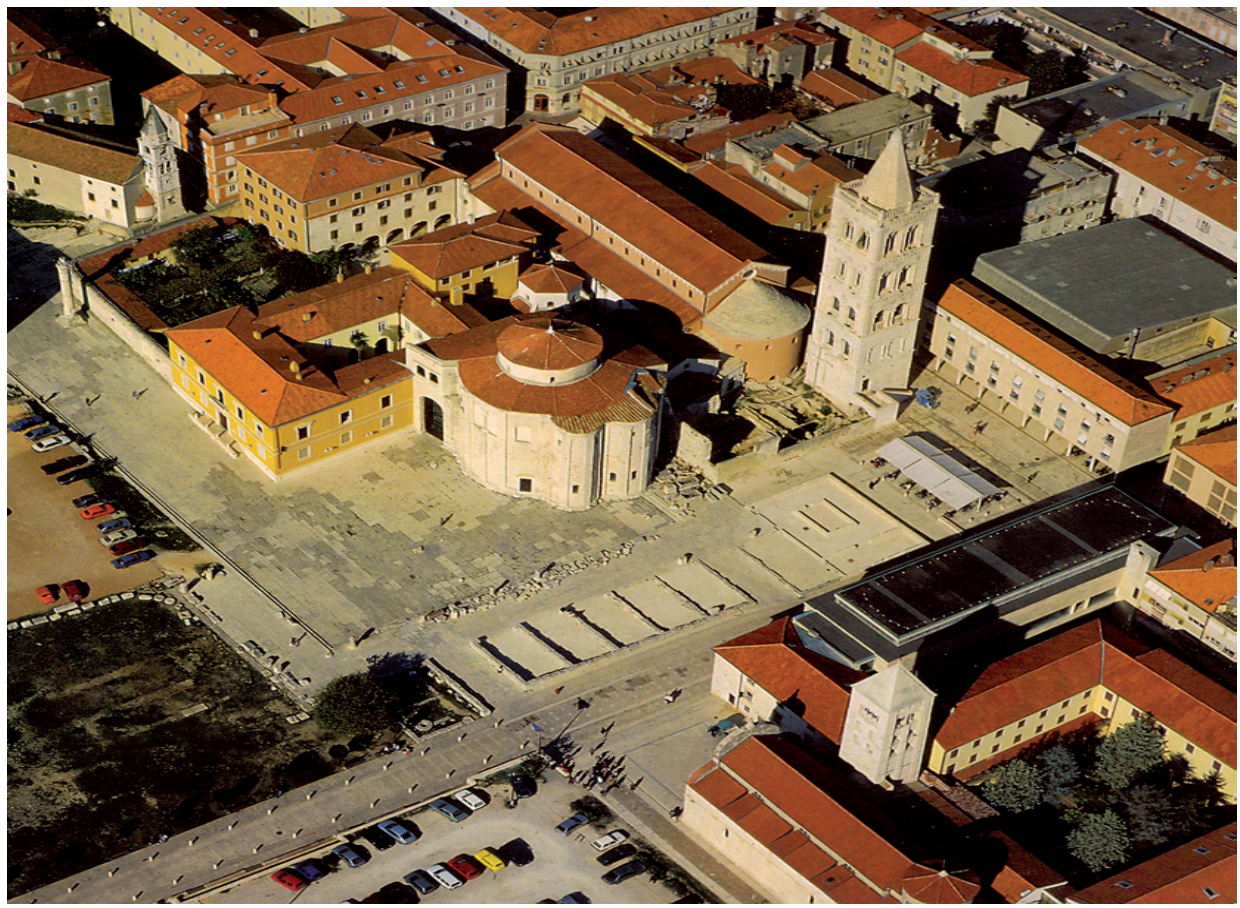

Figure 11 - City Zadar Roman Forum (Source: Vežić, 2001: 55)

As the concluding remark on this section, both cities experienced uninterrupted settlement and continuous urban planning and organisation of space. As the result, Trogir's and Zadar's urban space is derived from its public, private, secular or religious spaces (Jović-Gazić, 2012). As such, it represents one of the most valuable early medieval peninsula city heritage sites, particularly in relation to urban spatial planning. Urban space in medieval peninsula cities was also a hub of regional trade and this is discussed below.

\section{Economic traces}

Because of their municipality status, urban spaces in medieval peninsula cities were important regional hubs of economic activities from the sea trade, including fisheries and import and export from the regional Mediterranean Sea, as well as agriculture and farming from the surrounding hinterland. There was a concentration of sea trade in the eastern Dalmatian region and with the municipality cities of Zadar and Trogir playing a pivotal role as hubs of trading activities across the Adriatic Sea. Gluščević (1994) provides a starting point for exploring this theme in more depth. Once the goods arrived at the ports, they were transferred to the market square for sale. Market squares, as seen in Figure 12, were the places of exchange of the goods brought by the traders from the eastern Dalmatian region. 


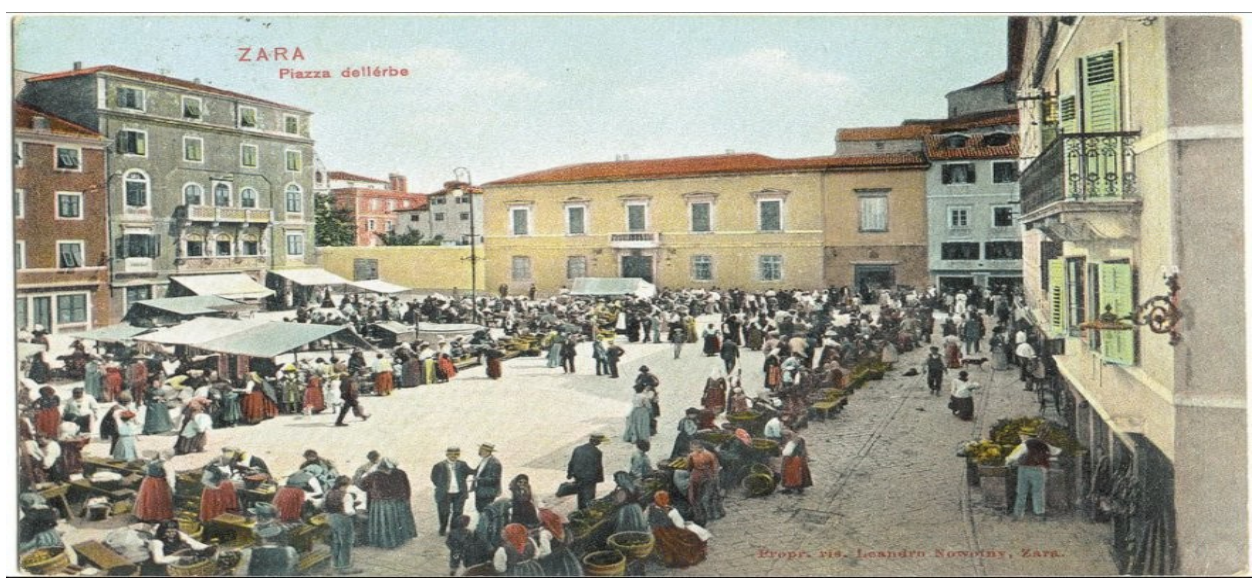

Figure 12 - Market in Zadar (C) VisiCro (nd)

In both medieval Zadar and Trogir, markets squares were usually constructed near the ports and were surrounded by the city gates that delivered the goods from the nearby ports and hinterland. They were connected by networks with the main streets, city gates and the local port. Surrounding the market were administrative offices where the sale deals were sealed and trade activities controlled by the city commune and authorities. Benyovsky (2006) provides in-depth insight into the organisation of the market place in medieval Trogir, based on an extensive analysis of the historical literature. Such organisation of the urban space within the peninsula cities also allowed for early trade censuses. It was estimated that the population of Trogir in the 13th Century was 1,500 and in the 16th Century around 3,0oo, while Zadar, on the other hand, had a population of 8,ooo in the 16th Century (Raukar, 1876). Madunić (2009), using the oldest preserved census of Dalmatian communes, dating back to 1527 , explores the structure of the society in Zadar in the 16th Century, including class groups (ie citizens, plebeians, patricians, clergy and Venetian and military government) and professional groups (ie artisans, craftsmen, tradesmen and sailors). This later period is of interest as it is useful to explore the development of the economic activities in that time. For example, Table 1 provides the frequency of certain occupations among the peninsula city traders or artisans.

Table 1 illustrates an interesting but typical mixture of the occupations within and beyond ancient Mediterranean peninsula cities such as Zadar and Trogir. It reflects the circumstances driving the economic prosperity and constant threats of occupation from the Venetian Republic. At the top of the table, the most popular professions were specialists in shoes and clothes, followed by the blacksmiths, coopers and shipbuilders. Because of their Roman municipality status in the Eastern Dalmatian region, Zadar and Trogir had a strong military, religious and administrative presence within their city walls. It seems logical that these groups were the main drivers of the demand for these trades. As Madunić (2009) argues, Blacksmiths' professional skills were necessary for the production of weapons. Moving down the table, we can see that bakers and butchers were also in demand and that this is consistent with the population size at the time. There are also groups of artisans that specialised in leather and tool production and their presence is consistent with the residing groups of the population. The thriving maritime industry needed all sort of artisans, from the shipbuilder, carpenter and builder to food artisans, as Table 1 suggests. With the sea trade orchestrated within the market squares, the fishing

Shima: The International Journal of Research into Island Cultures Volume 10 Number 12016

- 101 - 
industry was particularly dominant, hence the need to include this group separately. Table 2 illustrates the overview of the maritime professions within the group.

\begin{tabular}{|c|c|c|}
\hline Occupation & Total & $\%$ \\
\hline Shoemaker & 29 & 19.60 \\
\hline Tanner & 23 & 15.54 \\
\hline Tailor & 14 & 9.46 \\
\hline Blacksmith & 11 & 7.43 \\
\hline Cooper & 9 & 6.08 \\
\hline Shipbuilder & 9 & 6.08 \\
\hline Butcher & 8 & 5.40 \\
\hline Carpenter & 8 & 5.40 \\
\hline Baker & 6 & 5.40 \\
\hline Goldsmith & 4 & 2.70 \\
\hline Armourer & 3 & 2.03 \\
\hline Barber & 3 & 2.03 \\
\hline Fabric dyer & 3 & 2.03 \\
\hline Builders, stonemasons & 4 & 2.70 \\
\hline Wool comber & 2 & 1.35 \\
\hline Sausage maker & 2 & 1.35 \\
\hline Oil miller & 2 & 1.35 \\
\hline Pillow maker & 1 & 0.68 \\
\hline Crossbow maker & 1 & 0.68 \\
\hline Cutter & 1 & 0.68 \\
\hline Leather shoemaker & 1 & 0.68 \\
\hline Tinsmith & 1 & 0.68 \\
\hline Jeweller & 1 & 0.68 \\
\hline Painter & 1 & 0.68 \\
\hline Miller & 1 & 0.68 \\
\hline Total & 148 & 100 \\
\hline
\end{tabular}

Table 1 - Frequency of occupations amongst the citizens in peninsula city Zadar in the 15th Century (Source: adapted from Madunić [2009])

Table 1 illustrates an interesting but typical mixture of the occupations within and beyond ancient Mediterranean peninsula cities such as Zadar and Trogir. It reflects the circumstances driving the economic prosperity and constant threats of occupation from the Venetian Republic. At the top of the table, the most popular professions were specialists in shoes and clothes, followed by the blacksmiths, coopers and shipbuilders. Because of their Roman municipality status in the Eastern Dalmatian region, Zadar and Trogir had a strong military, religious and administrative presence within their city walls. It seems logical that these groups were the main drivers of the demand for these trades. As Madunić (2009) argues, Blacksmiths' professional skills were necessary for the production of weapons. Moving down the table, we can see that bakers and butchers were also in demand and that this is consistent with the population size at the time. There are also groups of artisans that specialised in leather and tool production and their presence is consistent with the residing groups of the population. The thriving maritime industry needed all sort of artisans, from the shipbuilder, carpenter and builder to food artisans, as 
Table 1 suggests. With the sea trade orchestrated within the market squares, the fishing industry was particularly dominant, hence the need to include this group separately. Table 2 illustrates the overview of the maritime professions within the group.

\begin{tabular}{|l|c|}
\hline \multicolumn{1}{|c|}{ Job type } & Total \\
\hline Sailor & 41 \\
\hline Fisherman & 4 \\
\hline Goods carrier & 8 \\
\hline Boatman & 1 \\
\hline Total: & 54 \\
\hline
\end{tabular}

Table 2 - Maritime occupations in Zadar in 15th Century (adapted from Madunić [2009])

In Table 2, the number of sailors exceeds all other occupations but this seems to be a balanced figure, given the demand for and current sea trade activities not only in the eastern Dalmatian region but in the whole of the Adriatic Sea. Goods carrier jobs were also in demand for the transfer of goods to and from the ships. The fishing trade, given the proximity of Zadar to the sea, supplied the city with the fish stock that formed a balanced diet for the Adriatic Sea population, including coastal cities and nearby island populations, while boatmen were in demand by ships. Tables 1 and 2 provide a useful overview of the demand and supply for city trade and maritime occupations that developed out of the peninsula city trading activities. Such a variety of artisan trades are clear signs of the economic prosperity in the early medieval period in the Adriatic Sea. This, and subsequent periods dominated by the occupation of the Venetian Republic have, consequently, provided solid foundations for a modern peninsula city spatial planning. In the newly founded independent Republic of Croatia, the Dalmatian region is again prospering. Ancient, urban and economic traces of today's peninsula cities such as Zadar and Trogir undoubtedly still influence today's economy in the Dalmation region, as illustrated in Table 3.

\begin{tabular}{|l|c|c|c|c|}
\hline \multicolumn{1}{|c|}{ Region } & $\begin{array}{c}\text { Gross domestic } \\
\text { product (millions } \\
\text { USD) }\end{array}$ & $\begin{array}{c}\text { Structure by } \\
\text { counties } \\
\text { (Republic } \\
\text { of Croatia =100) }\end{array}$ & $\begin{array}{c}\text { GDP per capita, } \\
\text { (thousands USD) }\end{array}$ & $\begin{array}{c}\text { Indices } \\
\text { (Republic of } \\
\text { Croatia }=100)\end{array}$ \\
\hline $\begin{array}{l}\text { Republic of } \\
\text { Croatia }\end{array}$ & 49,230 & 100.0 & 11,530 & 100.0 \\
\hline Zadar County & 1,565 & 3.2 & 9,147 & 79.3 \\
\hline $\begin{array}{l}\text { Split-Dalmatia } \\
\text { County }\end{array}$ & 4,012 & 8.1 & 8,818 & 76.5 \\
\hline
\end{tabular}

Table 3 - GDP and GDP per capita for the Republic of Croatia, at NUTS 2 Level and by counties 2012. (Source: Croatian Bureau of Statistics [N.D.])

\footnotetext{
${ }^{\text {" }}$ Currencies were converted using the values at the time of publishing, e.g. $1 €=1.12$ USD.
} 
In terms of the contribution to the state, Zadar (alone) and Trogir (included in the SplitDalmatia county) contribute around $11 \%$ to the national economy. This is a significant contribution and a noteworthy inheritance from history. Earlier, I spoke of the economic activities and trade occupations that developed in these peninsula cities in the 15th Century. Today, these occupations are still present, for example, agriculture and fishing as well as manufacturing and ship building, as seen in Table 4 .

\begin{tabular}{|l|c|c|}
\hline \multicolumn{1}{|c|}{ Sectors } & Zadar County & $\begin{array}{c}\text { Split-Dalmatia } \\
\text { County (incl. } \\
\text { Trogir) }\end{array}$ \\
\hline Agriculture, forestry and fishing & 5.2 & 3.7 \\
\hline Manufacturing, mining and quarrying & 9.1 & 4.4 \\
\hline Manufacturing (food) & 5.3 & 4.7 \\
\hline Construction & 7.9 & 9.7 \\
\hline $\begin{array}{l}\text { Wholesale and retail trade, transportation and storage, } \\
\text { accommodation and food service }\end{array}$ & 20.6 & 6.5 \\
\hline Information Communication & 1.7 & 6.9 \\
\hline $\begin{array}{l}\text { Financial intermediation, Real estate, renting and } \\
\text { business activities }\end{array}$ & 5.3 & 12.1 \\
\hline Real estate activities & 3.7 & 7.6 \\
\hline $\begin{array}{l}\text { Public administration and defence, social security, } \\
\text { education, health and social work }\end{array}$ & 17.0 & \\
\hline $\begin{array}{l}\text { Professional, scientific, technical, administrative and } \\
\text { support services }\end{array}$ & 7.5 & \\
\hline Other service activities & & \\
\hline Gross value added (basic prices) & 3.1 & \\
\hline
\end{tabular}

Table 4 - Share in Gross Value Added of Republic of Croatia, at NUTS 2 Level and by counties (2012) (Source: Croatian Bureau of Statistics [N.D.])

According to Table 4, wholesale and retail trade make up $20 \%$ of economic activites. This is followed by the administrative activities of $17 \%$, indicating the traditional use of the ancient urban space by this group. Agriculture, forestry and fishing remain important natural sources alongside various manufacturing activities. In addition, many specialised 
artisanal trades such as shoe and clothes making continue as cultural heritage elements that play an important part in regional tourism economy. It is important to recognise their significance, in both human and environmental terms, for regional tourism. Arguably, cultural heritage is "at the heart of what it means to be European, it is being discovered by both governments and citizens as a means of improving economic performance, people's lives and living environments" (CORDIS, 2016). Restoration of the many architectural ruins is expensive and involves laborious work but the value adding nature of the activity represents a future income stream. Tables 5 and 6 provide insight into investment in cultural heritage and tourism in Trogir and Zadar, respectively.

\begin{tabular}{|c|c|c|c|c|}
\hline & $\begin{array}{c}2014 \\
(\text { thousands } \\
\text { USD })^{12}\end{array}$ & 2015 & 2016 & 2017 \\
\hline $\begin{array}{l}\text { 1. TOURISM (e.g. cultural } \\
\text { programmes: promotion of } \\
\text { destinations, thematic footpaths, } \\
\text { technology - Hot Spot areas, } \\
\text { mobile applications) }\end{array}$ & 48,096 & 64,275 & 64,266 & 64,266 \\
\hline $\begin{array}{l}\text { 2. DEPARTMENT OF EU FUNDS } \\
\text { AND ECONOMIC } \\
\text { DEVELOPMENT (e.g. current } \\
\text { and capital projects) }\end{array}$ & 174,371 & 174,371 & 113,983 & 58,796 \\
\hline $\begin{array}{l}\text { 3. CRAFTS, SMALL AND } \\
\text { MEDIUM-SIZED ENTERPRISES } \\
\text { (e.g. incentives, measures and } \\
\text { support) }\end{array}$ & 18,374 & 33,808 & 19,109 & 19,109 \\
\hline $\begin{array}{l}\text { 4. AGRICULTURE (e.g. } \\
\text { incentive, measures and aid) }\end{array}$ & 8,816 & 8,816 & 8,816 & 8,816 \\
\hline $\begin{array}{l}\text { 5. DEPARTMENT OF } \\
\text { PLANNING, URBAN PLANNING } \\
\text { AND CONSTRUCTION (e.g. } \\
\text { restoration of cultural heritage } \\
\text { and investment) } \\
\end{array}$ & 472,716 & 938,348 & 733,777 & 634,579 \\
\hline $\begin{array}{l}\text { 6. ISLANDS (Čiovo, Veli \& Mali } \\
\text { Drvenik) (e.g. maintenance of } \\
\text { public areas, transport, } \\
\text { communal and social } \\
\text { infrastructure) }\end{array}$ & 38,197 & 38,197 & 38,197 & 38,197 \\
\hline
\end{tabular}

Table 5 -Budget for the city of Trogir 2014-2017 (Source: Grad Zadar [N.D.])

\footnotetext{
${ }^{12}$ Currencies were converted using the values at the time of publishing, eg $1 €=1.12$ USD

${ }^{13}$ Translated as "Uprava grada Trogira”
} 


\begin{tabular}{|c|c|c|c|c|}
\hline & $\begin{array}{l}2014 \\
(\text { thousands } \\
\text { USD })^{14}\end{array}$ & 2015 & 2016 & 2017 \\
\hline $\begin{array}{l}\text { 1. TOURISM (e.g. cultural } \\
\text { programmes: promotion of } \\
\text { destinations, thematic footpaths, } \\
\text { technology (Internet HotSpot } \\
\text { areas, mobile applications) }\end{array}$ & 416,688 & 761,271 & 654,993 & 741,075 \\
\hline $\begin{array}{l}\text { 2. DEPARTMENT OF EU FUNDS } \\
\text { AND ECONOMIC } \\
\text { DEVELOPMENT } \\
\text { (e.g. capital project: Restoration } \\
\text { of "Kneževska Palača" (heritage) } \\
\text { (e.g. current projects: protection } \\
\text { of environment, improving } \\
\text { human potential, green islands, } \\
\text { innovation through } \\
\text { collaboration) }\end{array}$ & 416,688 & $3,273,079$ & $3,433,936$ & 156,864 \\
\hline $\begin{array}{l}\text { 3. CRAFTS, SMALL AND } \\
\text { MEDIUM-SIZED ENTERPRISES } \\
\text { (e.g. incentives, measures and } \\
\text { support) }\end{array}$ & $3,411,394$ & $3,968,722$ & $2,870,331$ & $2,879,143$ \\
\hline $\begin{array}{l}\text { 4. AGRICULTURE (e.g. incentive, } \\
\text { measures and aid) }\end{array}$ & 102,813 & 102,813 & 102,813 & 102,813 \\
\hline $\begin{array}{l}\text { 5. DEPARTMENT OF } \\
\text { PLANNING, URBAN PLANNING } \\
\text { AND CONSTRUCTION (e.g. } \\
\text { preservation of cultural heritage } \\
\text { and investment) }\end{array}$ & $\begin{array}{l}\text { Under } \\
\text { tourism } \\
\text { section }\end{array}$ & $\begin{array}{c}\text { Under tourism } \\
\text { section }\end{array}$ & $\begin{array}{l}\text { Under } \\
\text { tourism } \\
\text { section }\end{array}$ & $\begin{array}{l}\text { Under } \\
\text { tourism } \\
\text { section }\end{array}$ \\
\hline $\begin{array}{l}\text { 6. ISLANDS (Veli \& Mali Iž, Rava, } \\
\text { Silba \& Olib). (e.g. maintenance } \\
\text { of public areas, transport, } \\
\text { communal and social } \\
\text { infrastructure) }\end{array}$ & 242,184 & 446,446 & 550,715 & 282,700 \\
\hline
\end{tabular}

Table 6 - Budget for the city of Zadar 2014-2017 (Source: Grad Zadar [N.D.])

\footnotetext{
${ }^{14}$ Currencies were converted using the values at the time of publishing, e.g. 1 HRK $=0.147062$ USD.
} 
Tables 5 and 6 represent the summarised budget figure related to the external and internal investments made and estimated by Trogir's city administration for the period 2014 to 2016. In considering the level of the investment, one needs to bear in mind the city's demographics, for example, population, city size and cultural heritage, at its disposal. The tables include six categories that require investment: 1. Tourism, 2. Department of EU fund and Economic Development, 3. Craft and small and medium enterprises, 4. Government subsidies for argiculture, 5. Department of Planning, including Urban Planning and 6. Islands. In promoting the cultural heritage, supporting the ancient craft and small business enterprises that specialise in preserving the ancient artisan trades and promoting the various touristic activities, appear to be a priority. Investment in urban planning includes a significant portion of the funds directed at the restoration of the architectural remains, including the EU funding that became available following Croatia's accession to the Union in 2013. In the case of Zadar, the Tourism section takes responsibility for cultural events related to restoration. These tables also highlight the role that peninsula cities have in the development of their nearby islands. Historical neglect over the last few centuries played a role in the decline of island life and coupled with high ferry prices, resulted in island emigration and social exclusion of island communities (Mendas, 2015). Peninsula cites like Zadar and Trogir represent a potential gateway to nearby islands. Zadar is linked by ferries to the nearby archipelago with national parks (Brijuni, Mljet and Kornati) while Trogir links to island Čiovo, famous for its royal churches and monasteries as well as being the habitat of many endemic species of plants and animals.

On a broader scale, traces of the events and material life explored in this paper are signs of cultural heritage. Investment in preserving cultural heritage plays an important part in developing the future regional tourism economy not just in the Mediterranean region but also in other parts of Europe. For example, in the Baltic Sea region, following the Lübeck Declaration adopted by the 3rd Conference of the Baltic Sea Region, CBSS Ministers of Culture (Lübeck, September 22nd 1997) the 1998 BONUS $^{15}$ initiative established the Baltic Sea Monitoring Group on Heritage Cooperation to monitor developments in building preservation and maintenance, underwater heritage, coastal culture, maritime heritage and sustainable historic towns. In the Mediterranean region, since 1998, the Euromed Heritage regional programme ${ }^{16}$ has allocated $€ 57 \mathrm{~m}$ in total for funding partnerships between conservation experts and heritage institutions from the countries of the Mediterranean region. In the North Sea Region, the Interreg Programme Preparation Group $^{17}$ consisting of representatives from the seven North Sea Region countries, launched a feasibility study in 2014 for a World Heritage cooperation programme with business partners, to identify new ways of working. There are also some concerns about the nature of continuous investment into cultural heritage. McManus (2005), in her investigation of Irish heritage, concludes that while tourism brings many economic benefits for local communities, there is also a trade-off in terms of the negative impact of tourism on environmental, social and cultural aspects. The current focus on treating cultural heritage as an economic asset serving a niche tourism market has overlooked the role that identity and heritage play in our everyday lives. In terms of island identity, Faričić (2010) poses the

\footnotetext{
${ }^{15}$ BONUS is the joint Baltic Sea research and development programme for years 2010-2017. Retrieved from: http://www.cbss.org/cultural-heritage/

${ }^{16}$ See http://www.euromedheritage.net/intern.cfm?menuID=7\&submenuID=1

${ }^{17}$ http://www.northsearegion.eu/about-the-programme/background/
}

Shima: The International Journal of Research into Island Cultures Volume 10 Number 12016 
question whether we should accept peninsulas as pseudo islands or forget their insular past and identity.

\section{Conclusion}

The main purpose of this paper has been to explore the ancient peninsula city from a historico-economic perspective and is devoted largely to the analysis of this concept. This paper contributes to a body of knowledge about durable material life (structures) in medieval Croatia and the Adriatic Sea and, thus, presents a modest attempt to operationalise Braudel's and Bloch's methodological approaches within this domain. More specifically, it touches upon the subject of medieval Mediterranean economic and social structures: including artisan professions, religious and political spheres, and how they ordered their affairs and what held them together in durable structure of space and time. Perroux's framework of the economic space and traces, in Derrida's sense, provide a useful but nevertheless practical and modest extension of Braudel's longue durée. This was articulated with the reference to ancient, urban and economic traces that led to economic prosperity in peninsula cities connected by bridges or canals, or both, for economic and political reasons. In the longue durée, this resulted in establishing the peninsula city space within Zadar and Trogir that evolved to have a specific purpose of consolidating a nexus of political power around which economic, religious and social life thrived. This gives additional support to the conclusion that ancient, urban and economic traces support the important role of the peninsula city space as a precedent in emerging contemporary natural and cultural heritage tourism. The preservation of their identity should be seen as a driving force in planning strategies but this requires local city planners to engage more closely with the public and policy makers to further explore the value of the peninsula city space to both local and regional heritage tourism.

\section{BIBLIOGRAPHY:}

Baldacchino, G (2014) 'Capital and Port Cities on Small Islands Sallying Forth beyond Their Walls: A Mediterranean Exercise', paper presented at the ist Island Cities and Urban Archipelagos Conference in Copenhagen

Benyovsky-Latin, I (2009) Srednjovjekovni Trogir. Prostor i društvo / Medieval Trogir: Space and Society, Zagreb: Hrvatski Institut za Povijest

Bloch, M (1953) The Historian's Craft (translated by Peter Putnam), New York: Alfred A. Knopf

Braudel, F (1981) Civilisation and capitalism $15^{\text {th }}-18^{\text {th }}$ Century: The Structures of Everyday life - The Limits of the Possible v1 (translated by Miriam Kochan [1973] revised by Siân Reynolds) London: Collins

(1982) Civilisation and capitalism $15^{\text {th }}-18^{\text {th }}$ Century: The Wheels of Commerce v2 (translated by Siân Reynolds), London: Collins 
(1984) Civilisation and capitalism 15th-18th Century: The Perspective of the World v3 (translated by Siân Reynolds), London: Collins

(1992) The Mediterranean and The Mediterranean World in the Age of Philip II (translated by Siân Reynolds), London: Harper Collins

Budak, N and Raukar, T (2006) Hrvatska povijest srednjeg vijeka, Zagreb: Školska knjiga

Chevalier, P (1995) Ecclesiae Dalmatiae, L'architecture paleochrétienne de la province romaine de Dalmatie (IVe -VIIe s.) I-II [Salona II], Rim - Split, Rome: Publications de l'École Française de Rome: 194

CORDIS (2016) 'Special Issue: Preserving our cultural heritage', research*eu results magazine $\mathrm{n} 49$

Croatian Bureau for Statistics (nd) Statistical Reports: Population by Nationality, by town/municipalities, 2011 Census

Croatian Bureau of Statistics (nd) Statistical Reports: GDP and GDP Per Capita for Republic of Croatia, at NUTS 2 Level and by counties 2012

Croatian National Tourist Board (nd): http://croatia.hr/en-GB - accessed February 2oth 2016

Daru, P (1819) Histoire de la Republique de Venise, Paris: Firmin Didot

Desfor, G and Jørgensen, J (2004) 'Flexible urban governance: the case of Copenhagen's recent waterfront development', European Planning Studies v12 n4: 479-496

Faričić, J and Mirošević L (2014) 'Artificial peninsulas and pseudo-islands of Croatia', Annales Ser.hist.social v24 n1: 113-128

Gluščević, S. (1994) 'Brodolomi na Jadranu u antici i srednjem vijeku’, Adrias n4-5: 13-32

Gold, A (2016) ‘Gibraltar: A Paradigmatic Presquile?', Shima: The International Journal of Research into Island Cultures v10 nı: 1-12

Grad Trogir (nd) Proračun Grada Trogira. Retrieved from:

http://www.trogir.hr/GradTrogir/proracun.

Grad Zadar (nd) Proračun Grada Zadra. Retrieved from:

http://www.grad-

zadar.hr/repos/doc/Proracun\%2oGrada\%2oZadra\%2oza\%202015.\%2ogodinu\%5B1\%5D.pdf

Grydehøj, A (2015) 'Island City Formation and Urban Island Studies’, Area n47 v4: 429-435

Jović-Gazić, V (2012) 'Urban development from late Antiquity to the middle ages: Dubrovnik, Split, Trogir, Zadar - The state of research', Archaeologica Adriatica v7 nı: 151196 


\section{Mendas: Zadar and Trogir}

Klaić, N and Petricioli, I (1976) Zadar u srednjem vijeku Zadar do 1409, Zadar: Filozofski fakultet

Kovačić, V (1993) 'Prilozi za ranokršćansku topografiju Trogira', Diadora n15: 291

------ (1997-1998) 'Trogirske fortifikacije u XV'stoljeću', Prilozi povijesti umjetnosti u Dalmaciji n37: 109-137

Lučić, J (1980) 'Komunalno uređenje dalmatinskih gradova u XI - Stoljeću', Zbornik zavoda za povijesne znanosti istraživačkog centra JAZU: 209-233

Madunić, D. (2009) 'Mjera grada: zadarski popis stanovništva 1527. godine', Povijesni prilozi, 36, 23.-63. Zadar: Zavod za povijesne znanosti HAZ

Marković, M. (2001) Hrvatski gradovi na starim planovima i vedutama, Zagreb: AGM

McManus, R (2005) 'Identity crisis? Heritage construction, tourism and place marketing in Ireland' in McCarthy, M (ed) Ireland's heritages: Critical perspectives on memory and identity, Aldershot: Ashgate: 235-255

Mendas, Z (2015) 'Tracing socio-economic impact of ferry provision in Zadar island archipelago', Journal of Marine and Island Cultures v4 n1: 10-26

Museum of City Trogir (nd) Retrieved from: http://muzejgradatrogira.blogspot.co.uk

Pigou-Dennis, E and Grydehøj, A (2014) 'Accidental and ideal island cities: islanding processes and urban design in Belize City and the urban archipelagos of Europe', Island Studies Journal v9 n2: 259-276

Raukar, T (1969, 1970) 'Zadarska trgovina u XIV i XV stoljeću', Radovi Filozoškog Fakulteta, Zagreb: Odsjek za povijest: 1969: 7-8; 1970: 19-79

State Archive Split (nd) Comune Traù; Dalmazia Circolo di Spalati 1830, Box 659, No: 203 UNESCO. Retrieved from: http://whc.unesco.org/en/news/18o/

Vernant, J (1965) Mythe et pensée chez les Grecs: étude de psychologie historique, Paris: Francois Maspero

Vežić, P (2001) 'Po čemu je u 10. Stoljeću katedrala u Zadru mogla sličiti halkopratejskoj bazilici u Carigradu', Diadora n20: 301-313

Visit Croatia (nd) Retrieved from: http://www.visitcro.com/hr/

Zadar Tourist Board (nd) Retrieved from: http://www.zadar.travel/en/about-zadar 